\title{
中共と日本の写真測 量
}

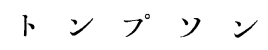

"A Note on Photogrammetry and Surveging in China and Japan"

Photogrammetric Record. Уol. IV, No. 24, 1964, p. 503 505.

ロンドン大学 E.H. Thompson 教授は昨年春北京で開かれた科学機械の展示会に関連し て中共を訪れ，北京と武漢とで講演を行なった。ついで日本に立寄られわれわれも同教 授の講演を聞く機会をもつことができた。その折の同教授の印象を同行の人が英国写真測 量学会誌に記載している。中共ではソ連方式を基準としていることがうかがえて興味ある ので，その大要を抄訳した。（抄訳者中村貢治）

\section{1. 中共における写真測量}

中共政府は国土開発に測地と測量の重要なことを 認め, 教育に力を入れ, 1956 年, 漢口に測量測地 大学 (Collage of Survey and Geodesy) を設立し た。同大学の写真測量学部長である Wang Chi-Cho 教授は 1949 年前の上海大学では, 測量を学ぶ学生 は2 名を越えることはなかったと語っていた。新大 学は学生 2,500 名, 教授助教授 20 名, 教師 80 名 を含むスタッフ 350 名の規模で, 土木測量, 空中写 真測量, 天文測地, 地図, 機械設計の 5 学部にわか れている。学部の選択はスタッフによって決められ る。全過程 5 力年で, 基礎過程と専門過程とがあっ て, , 政治教育は強制的に行なわれ, 英語かロシア 語は必須課目で，その他の外国語は撰択課目となっ ている。その他通信講座もある。卒業後は作業, 研 究, 教育の各分野に割当てられる。

教授は時間の関係で天文測地学部と写真測量学部 のみしか見られなかった。天文測地学部はよく整備 されていたが，写真測量学部は低いレベルにあるよ うに見えた。広角と超広角のムルティプレックスと ラジアル法と視差測定法とを基準としたもので，東 ッアイスのムル 40 灯があった。視差測定には東ツ アイスかソ連製のステレオコンパレー夕を用いる方 法も行なわれていた。ムルの単プロジェクタで偏位 修正し写真等高線(ホトマップか? ) に変換する方法 を行なっていた。図化機は東ッアイスのステレオプ ラニグラフ 1 台と, ウイルドの A8 が 1 台だけであ った。解析写真測量は教えられてなかったが，これ についての質問があって, 実施していないが良く教 育されているように考えられ，同教授の論文は全て 読まれていた。図書館は学生用 4 スタッフ用 1 むあ り，良く整っていた。
中共のような巨大で，開発未開発両方ある地域で は資源利用のため各種の地図が必要で，中共政府は このことを良く理解して，良いスタートを切ったこ とを誇りとしていた。

I.S.P. に対しては関心を示していたが，その招待 を拒絶していたのは理解できない。

\section{2. 日本における写真測量}

中共においてはすべての活動が政府によって高度 に組織化されているが，日本に抢いては歴史的理由 によってそれが民間企業において行なわれていて， その数はいかなる国よりも多い。大戦前での測量活 動は全て日本陸軍の手にあったが，解体されてしま った結果小さい政府機関，G.S.I. となった。解散 された陸地測量部々員をスタッフとして設立された 約 20 の民間会社と契約するための仕様書や計画を 書くのが G.S.I. の主体である。これらの会社の中 で, 4 社が大きく，その中の二社国際とアジアとを 見たが，近代的図化機が設備されていた。アジアで は自分で設計した機械を用いて単眼測定して解析空 中三角測量を行なっていた。相間標定はステップ・ バイ・ステップ法で行ない，ストリップとブロック の平均をデイジタル法で行なっていたことは興味あ ることで，しかもこれを企業体で実施していること は輝かしいことである。

J.S.P. で講演したが良く理解され，ブロック平均 を含む解析法に興味をもって質問を受けた。

日本に打ける写真測量は機械製作の面を除くと西 ヨーロッパの水準で, I.S.P. の 国際会議を 東京で 開く可能性があり, その時は日本の写真測量家達は ヨーロッパの人々に多くのことを示してくれるであ ろう。 